\title{
What Stymies Action on Climate Change? Religious Institutions, Marginalization, and Efficacy in Kenya
}

\author{
Lauren Honig, Amy Erica Smith, and Jaimie Bleck
}

\begin{abstract}
Addressing climate change requires coordinated policy responses that incorporate the needs of the most impacted populations. Yet even communities that are greatly concerned about climate change may remain on the sidelines. We examine what stymies some citizens' mobilization in Kenya, a country with a long history of environmental activism and high vulnerability to climate change. We foreground efficacy — a belief that one's actions can create change—as a critical link transforming concern into action. However, that link is often missing for marginalized ethnic, socioeconomic, and religious groups. Analyzing interviews, focus groups, and survey data, we find that Muslims express much lower efficacy to address climate change than other religious groups; the gap cannot be explained by differences in science beliefs, issue concern, ethnicity, or demographics. Instead, we attribute it to understandings of marginalization vis-à-vis the Kenyan state — understandings socialized within the local institutions of Muslim communities affected by state repression.
\end{abstract}

A list of permanent links to Supplemental Materials provided by the authors precedes the References section.

*Data replication sets are available in Harvard Dataverse at: https://doi.org/10.7910/DVN/R7XT2D

Lauren Honig is Assistant Professor of Political Science at Boston College (lauren.honig@bc.edu). Her research interests include citizen-state relations, land rights, and informal institutions in Africa. Her research has been funded by the Social Sciences Research Council, Fulbright Program, and the National Science Foundation.

Amy Erica Smith (1) is Associate Professor of Political Science as well as a Liberal Arts and Sciences Dean's Professor at Iowa State University (aesmith2@iastate.edu). In the 2020-2022 academic years, she is an Andrew Carnegie Fellow. Her research examines political behavior, democracy, representation, and religion in the developing world.

Jaimie Bleck is Associate Professor of Political Science at the University of Notre Dame (Jaimie.Bleck.1@nd.edu). She works on citizenship, governance, civil society, and elections in Africa. Her research has been funded by the Spencer Foundation, USAID'S Center of Excellence on Democracy, Human Rights and Governance, the American Council of Learned Fellows, and the National Science Foundation.
9 lobally, communities that had little role in creating climate change are bearing the brunt of its effects. Large populations in non-industrialized countries depend on predictable rains, fertile land, and healthy fisheries; they have higher exposure to extreme weather than citizens in developed countries, yet fewer resources to invest in adaptation (Notre Dame Global Adaptation Initiative 2019). Two-thirds of Africans surveyed between 2016 and 2018 who had heard of climate change reported that it negatively affects their lives (Selormey and Logan 2019). These concerns fuel activism. Citizens mobilize protests, contact politicians, and start social media campaigns to advocate for effective mitigation and adaptation policies. Even in countries that are not the primary drivers of climate change, citizen pressure on national governments can counterbalance big international firms, such as plastics lobbyists, and can force governments to exert influence over major polluters (Hadden 2015; Riofrancos 2017). Further, citizen input is critical for local policymaking. Although climate goals can be set at the national level, local governments often have a decisive role in crafting and implementing policy (Ojwang et al. 2017). A core insight of environmental justice movements is that local efforts must incorporate the perspectives of marginalized communities to meet citizens' needs effectively (Schlosberg 2004). In sum, local and national citizen engagement ensures that climate policy solutions serve impacted populations. 
However, despite its salience, this issue does not prompt action from all citizens equally. Even groups that care passionately about the cause may abstain from participation because they do not believe they can influence the government. Efficacy-the belief that one's actions can create change-links environmental concerns to activism (Lubell, Zahran, and Vedlitz 2007; Mohai 1985; RoserRenouf et al. 2014).

The case of Kenya illuminates the determinants of environmental efficacy in non-industrialized countries more broadly. Kenya is highly impacted by climate change. In recent years, the country has experienced many extreme weather events, from droughts to deadly floods. Kenyans also have an established repertoire of environmental activism and progressive environmental policies, from Wangari Maathai's Green Belt Movement to the 2017 plastic bag ban (e.g. Maathai 2003; Michaelson 1994). Therefore, it is not surprising that Kenyans' environmental efficacy is among the highest on the African continent (refer to the online appendix). However, not all Kenyans feel empowered to combat climate change. Even in a context of high environmental activism and concern, citizens' efficacy is uneven across the country.

To understand what stymies environmental efficacy, we consider the prominent hypothesis that religion shapes environmental outlooks. Globally, religious affiliation correlates with climate change attitudes (Arbuckle and Konisky 2015; Lewis, Palm, and Feng 2019; McCright and Dunlap 2011; Veldman 2020). Religious institutions generate frames communicating the existence, causes, and urgency of climate change. In Indonesia, for instance, Muslim civil society organizations urge citizens to respond forcefully to the threat (Amri 2013), a stance rooted in what Islamic scholars identify as the doctrine's ecological values (Izzi Dien 2000; Saniotis 2012). Through Laudato Si', Pope Francis similarly mobilizes Catholics globally. Religious leaders have access to powerful strategies of persuasion and wide-ranging mobilizational frames (McClendon and Riedl 2019). Kenya features a high level of religious diversity, making it a propitious setting in which to examine how religious institutions shape agency, even within a polity in which many citizens are actively working to combat climate change. We find that membership in religious institutions does, in fact, impact efficacy in Kenya. However, we provide evidence that these impacts are not through doctrinal and ideological persuasion alone. Instead, they reflect experiences of group marginalization vis-à-vis the state, which are channeled through religious institutions.

Group marginalization can suppress citizens' beliefs in their abilities to effect change. Efficacy develops through a learning process, reflecting prior experiences engaging the state (Beaumont 2011; Finkel 1985; Hunt 2014; Mettler and Soss 2004). Feelings of representation and experiences successfully impacting policy change increase a citizen's sense of agency (Finkel 1985). However, the perception that the state has underrepresented, neglected, or oppressed one's group decreases citizens' expectations that their actions will elicit a systemic response (Abramson 1972; Parker and McDonough 1999; Sidanius et al. 2016). Religious institutions and other community institutions sometimes channel marginalization into enhanced collective action (McDaniel 2009; McAdam 1999), but they can also reinforce the perception that action is futile, in order to protect members against harassment and repression. Thus, community institutions shape the relationship between marginalization - a property of individuals and groups-and efficacy.

Kenya's Muslims share a history of low representation in government and exclusion from the state (Elischer 2019; Ndzovu 2014). Recent Kenyan efforts to root out support for al-Shabaab and other extremist groups have increased that sense of marginalization (Mogire and Mkutu Agade 2011). Analyzing Afrobarometer surveys as well as nine focus groups and sixteen semi-structured clergy interviews in urban and rural Kenya, we show that Muslims express lower beliefs in their ability to impact environmental change than Christian peers of any denomination. We find that these differences do not result from differing exposure to or scientific beliefs about climate change. Instead, we argue that political marginalization, as experienced by individuals and shared within community institutions, limits Muslims' efficacy.

Climate change has far-reaching impacts and requires a coordinated political response; this research reveals why some communities are less likely to engage. Scholars have demonstrated how membership in institutions can increase individuals' ability to advance their interests through collective action (Hadden 2015; Ostrom 1990). Less understood, however, is under what circumstances institutions reinforce the decision not to act. In examining what stymies efficacy in relation to environmental issues, we respond to the call for more political science research on responses to climate change (Javeline 2014) — an issue that is particularly understudied in non-industrialized countries. We demonstrate that experiences of historical and contemporary discrimination within the state can have long-lasting effects on which citizens participate in climate change activism. Without increased attention to the impacts of marginalization on efficacy, climate change policies will fail to meet the needs of vulnerable populations. Our study thus highlights the need for policy interventions to engender participation among marginalized groups - a key to creating inclusive climate change solutions.

\section{Marginalization, Political Efficacy, and Community Institutions}

Efficacy is an essential component of activism-linking concerns to action. In a basic model of collective action, citizens engage as a function of issue salience and perception 
of agency (i.e., efficacy). ${ }^{1}$ These two attitudes correspond to the "B term" and the "p term" in a simple cost-benefit model of participation. In the case examined here, the " $\mathrm{B}$ term" reflects the level of concern about climate change (i.e., "Benefits"), whereas the "p term" reflects the probability of one's action affecting the outcome (i.e., probability) (e.g., Riker and Ordeshook 1970). Even issues with extremely high salience will not translate into action without the accompanying belief that collective action will be fruitful.

Our conceptualization of environmental efficacy builds on scholarship on political efficacy. The latter refers to individuals' beliefs that the political system will respond to them (Mokken 1971); in the African context, political efficacy is strongly linked to political participation (Hern 2019). Similarly, citizens' perceptions of their own ability to impact environmental outcomes-a construct we term "environmental efficacy"-is a critical determinant of environmental activism and mobilization (Ahn et al. 2015; Cleveland, Kalamas, and Laroche 2005; Hines, Hungerford, and Tomera 1987; Lam 2006). ${ }^{2}$

Efficacy is both domain-specific and contextual; it entails citizens' evaluations of the outside world and their roles within it. Scholars often distinguish between two dimensions of efficacy: internal and external (Balch 1974; Coleman and Davis 1976; Morrell 2003; Niemi, Craig, and Mattei 1991). Whereas internal efficacy reflects the "individual's beliefs that means of influence are available to him" (Balch 1974, 24), external efficacy assesses external forces' likely response to individual actions. Internal efficacy should depend on factors such as individual resources and social networks; in the domain of environmentalist action, external efficacy might depend on perceptions of both state responsiveness and the sources of climate change. As a result, institutions at multiple scales likely shape citizens' environmental efficacy: from community groups and schools to local and national government.

Early socialization molds both internal and external efficacy. For example, foundational scholarship on American politics highlights that education and civic skills endow individuals with the confidence that they are equipped to participate effectively in politics (Brady, Verba, and Schlozman 1995). Similarly, citizens grow in internal efficacy as they acquire information about the political system (Nie, Powell, and Prewitt 1969). Across the developing world, citizens learn efficacy through civic education (Finkel 2003; Finkel and Smith 2011). In Mali, attending school, and particularly gaining fluency in French, the bureaucratic language, empowers citizens to interact with the political system (Bleck 2015). Yet social learning is context specific. Friedman et al. (2016) find no effect of girls' secondary education on efficacy in Kenya. In Zimbabwe's authoritarian context, Croke et al. (2016) find that higher levels of education are associated with reduced participation, due to deliberate disengagement.
Beyond education, past interactions with the government inform individuals' evaluations of whether activism might succeed (Chamberlain 2012; Roser-Renouf et al. 2014). Hern (2019) argues that citizens feel empowered to act politically when they think that government is making efforts to provide services, while political elites perceived as untrustworthy or incompetent reduce "group efficacy" (Lubell, Zahran, and Vedlitz 2007). Social policies can also affect citizen agency (Hunter and Sugiyama 2014), as can institutions ranging from direct democracy (Bowler and Donovan 2002) to electoral rules (Karp and Banducci 2008) to regime types (Coleman and Davis 1976). Analyzing a panel survey, Finkel (1985) shows that past participation impacts subsequent expectations of systemic responsiveness. The development of political efficacy is thus a dynamic process of "sociopolitical learning" (Beaumont 2011). Efficacy is constructed over time, as citizens internalize past experiences and build expectations of their own future agency vis-à-vis the state.

Marginalization constitutes a form of group-based learning that saps citizens' confidence in their own potential impact. Marginalization describes a persistent and structural position as a historically discriminated group in society or the political system. Social dominance theory argues that marginalization stymies non-dominant group members' efficacy and willingness to confront the system (Sidanius et al. 2016). By limiting access to resources, marginalization leads citizens to question their own abilities. For instance, a dearth of visible political role models saps women's internal efficacy (Thomas 2012). In addition, socialization as a second-class citizen can inhibit external efficacy, generating alienation and making citizens doubt whether the state will respond to their voices. In the United States, for instance, African Americans' negative encounters with a "predatory system of government" that engages in "extractive policing" depress political participation and trust in the U.S. government (Lerman and Weaver 2014; Soss and Weaver 2017; Weaver and Lerman 2010; White 2019). In short, negative experiences with the state diminish efficacy.

Marginalization is not solely an individual experience, but one shared within communities. Consequently, community institutions shape perceptions of and responses to oppression (Case and Hunter 2012). By "community institutions," we mean socially identified, locally bounded groups that generate forums for interaction, sets of formal or informal rules, and social hierarchies; examples range from religious congregations to neighborhood gangs. Repeated interactions within community institutions often reinforce marginalization. First, discussion among members who experience similar discrimination may amplify mistrust in the state or perceptions of nonresponsiveness. Second, independent of personal experiences, citizens learn from other group members' experiences, internalizing the perception of collective marginalization 
through shared narratives. Third, leaders bear witness to and recount the experience of marginalization; they may discourage certain types of political action, shape assessments of likely state responses, or provide or limit resources for participation. Groups targeted by the state might urge members to avoid mobilization, seeking to protect vulnerable members by socializing them to be cautious in interactions with the state and larger society. In most circumstances, community institutions serving marginalized populations will rationally draw inward, reinforcing narratives of marginalization in an effort to prevent further oppression of group members. All of these mechanisms at the community level may further erode citizens' confidence in governmental responsiveness and their efficacy.

Nonetheless, under exceptional circumstances, community institutions instead increase marginalized populations' efficacy. Black churches in the United States are a notable example. Scholars agree that historic marginalization has profoundly shaped African Americans' agency and participation, producing low trust in government. ${ }^{3}$ For example, Parker and McDonough (1999) show that historical marginalization inhibits environmental activism, despite African Americans and white Americans having similar environmental concerns. However, churches leverage resources, networks, and hierarchies to channel action to address core group concerns, defying anticipated repression (McAdam 1999). They transmit information about key issues and mobilize congregants into politics (McDaniel 2009). Further, churches generate opportunities for citizens to learn and exercise civic skills (Verba, Schlozman, and Brady 1995). As a result, African American churches have been a "platform for political learning" that helps communities overcome barriers to participation (Wald and Calhoun-Brown 1997, 285).

Echoing McAdam and Boudet (2012), we argue that at least three conditions hold in cases where marginalized communities' institutions increase efficacy and mobilization. First, leaders must identify a suitable political opportunity structure; institutions operating under moderate but not extreme repression are better able to advance empowering narratives. Second, scholars emphasize the role of resistance narratives that identify structural oppression, while simultaneously encouraging political action (Case and Hunter 2012). Shingles argues that the development of Black consciousness empowered African Americans, enabling them to shift the locus of blame for poverty to the government $(1981,89)$. Third, marginalized communities are most likely to surmount barriers to activism in response to issues framed as immediate threats to the community's way of life or survival. For example, in the Democratic Republic of Congo, Muslim institutions overcame political exclusion to mobilize for government support of religious schools (Leinweber 2012). In the United States, migrant populations have channeled experiences of marginalization into collective action in response to perceived threat (Ramírez 2013; Zepeda-Millán 2017). As a result, climate change is a less propitious issue for marginalized groups' mobilization under most circumstances, because it is not usually immediately urgent for survival. Only when environmental problems become imminent (i.e., local factories that pose a severe health threat, or mining-related pollution in indigenous reservations) do marginalized communities mobilize for environmental justice (McAdam and Boudet 2012). While scholars often emphasize that community institutions can solve collective action problems (e.g., Magaloni, Díaz-Cayeros, and Ruiz Euler 2019; Ostrom 1990), sustained marginalization does not easily translate into increased efficacy. Absent specific conditions, narratives shared within marginalized community institutions often reinforce the effects of systemic discrimination on individuals' beliefs in their ability to effect change.

Thus, community institutions are prisms that refract marginalization, producing a spectrum of outcomes. In some circumstances, institutions channel marginalization into greater efficacy and activism, yet in other cases, they reinforce marginalization, reducing efficacy and activism. However, the impact of marginalization on efficacy has been under-explored in the context of the Global South. The following section presents the case of marginalized Muslim institutions and climate change policy in Kenya and our expectations in context.

\section{The Case of Kenya}

\section{Climate Change and Environmental Activism}

Climate change is a high-salience issue in Kenya that is currently impacting citizens' lives. Kenyans have observed many extreme weather events in recent years, including droughts, flooding, and storm surges (Ongoma, Chen, and Omony 2018). In a 2013 Pew survey, 57\% of Kenyans perceived climate change as the top global threat (Kohut 2013). By 2018, this had increased to $71 \%$ (Poushter and Huang 2019).

At the time of fieldwork in 2018, Kenya had been experiencing substantial climate instability. Consider, for example, reporting in the Daily Nation newspaper over the six months prior to the August 2017 elections. ${ }^{4}$ A sample of news stories provides a snapshot of the environmental topics discussed. Weather changes, such as drought and flooding, were by far the most frequently referenced issues. Although few instances were explicitly tied to climate change, and political campaigns did not incorporate climate change discourse, media coverage described how extreme and unpredictable weather was affecting Kenyans' lives.

Awareness of the science of climate change in Kenya is high, given the country's long history of environmental activism. In 1977, Wangari Maathai, a university professor and eventual member of Parliament, founded the Green Belt Movement to address deforestation, mobilizing rural 
women to plant trees and educate citizens on "ecological destruction" (Hunt 2014). The "consensus movement," which eventually earned Maathai a Nobel Peace Prize, raised consciousness of environmental issues broadly (Michaelson 1994, 546). In recent years, energy waste and pollution have also become increasingly topical, contributing to a nationwide plastic bag ban in 2017. The Green Belt Movement's current platform includes efforts to aid rural communities in addressing climate change by restoring and protecting forests. In sum, due to Kenyan citizens' long history of environmental activism and recent exposure to extreme weather, combatting climate change is a high-priority issue.

Unlike concerns that can be resolved through local collective action, such as self-help campaigns to build schools absent state intervention, climate change mitigation and adaptation also require policy responses. At the national level, Kenyans mobilize to demand global trade policies and regulations that combat climate change. When Kenyan president Uhuru Kenyatta faced pressure from the oil and plastics industry to remove the country's ban on importing plastic waste from the United States and other countries in 2020, engaged citizens countered with domestic political pressure (Tabuchi, Corkery, and Mureithi et al. 2020). Kenyans also mobilize at the local level, in part because environmental problems vary within the country. For example, drought-induced losses of livestock and crops are top concerns for climate change mitigation and adaptation in rural areas, but urban citizens may prioritize improved waste management and infrastructure to protect against cholera outbreaks (Moser et al. 2010). Even within rural areas, the interests of underrepresented groups such as pastoralists diverge from those of citizens practicing settled agriculture. When marginalized populations are excluded from contentious policy processes, solutions risk neglecting the needs of impacted populations. Thus, climate change is a critical issue for understanding how membership in marginalized communities shapes expectations of systemic responses, and, ultimately, policy design.

\section{Muslim Marginalization in Kenya}

In 2007, then-presidential candidate Raila Odinga promised to initiate "deliberate policies and programmes to redress historical, current and structural marginalisation and injustices on Muslims in Kenya" in a signed a memorandum of understanding with the National Muslim Leaders Forum (NAMLEF). ${ }^{5}$ As this document reveals, the historical and contemporary experience of marginalization is understood and discussed among Kenyan Muslims. In recent years, the state's "terrorism policy," responding to international pressure for counterterrorism, has intensified discrimination against Muslims (Barkan 2004; Mogire and Mkutu Agade 2011). Yet this policy is a continuation of a long history of Muslim marginalization and underrepresentation (Elischer 2019; Ndzovu 2014; Oded 2000; Vittori, Bremmer, and Vittori 2009).

Muslims in Kenya are a large minority group that traverses divides impacting political representation and power, including geography and ethnicity. They represent between $10 \%$ and $20 \%$ of the population; ${ }^{6}$ as Ndzovu (2014, 8-9) describes, such statistics themselves are a point of contention, with Muslim leaders accusing the state of underrepresenting their communities in the census. While Muslims live throughout the country, they are more highly concentrated in the Northeast and Coastal regions and in Nairobi. The Kenyan Muslim political identity features "a sociocultural heterogeneity that cuts across" race and ethnicity (Ndzovu 2014, 7). Half of Kenya's Muslims are ethnically Somali, producing a layered sense of exclusion based on ethnicity, religion, and contested citizenship; Muslims of Somali or Arab descent often face additional discrimination as "foreigners" (Ndzovu 2014, 117). Uniting them with Muslims from ethnic groups considered "Kenyan" is a shared history of marginalization.

Many Muslims believe that the state has targeted their communities and feel discriminated against when pursuing public jobs and education (Vittori, Bremmer, and Vittori 2009). Muslim-majority areas tend to receive more limited state infrastructure than other regions (Barkan 2004). In Nairobi, with an estimated 80 to 120 Muslim congregations, Muslims describe harassment and suspicion from state agents (Cussac and Goms 2010, 253). A report from the Truth, Justice and Reconciliation Commission of Kenya (2008) found that Muslim Kenyans often face excessive vetting and difficulty or denials in obtaining identity cards and passports, affecting access to public services like schooling. In the Muslim-majority Northeast Province, the government has frozen access to identification cards due to concerns about "foreigners" accessing them (Ndzovu 2014, 4).

These experiences are exacerbated by a sense of exclusion from political power. At independence, Christian missionary education was the pathway to political and administrative office (Cussac and Goms 2010). It was not until 1982 that a Muslim was appointed to a ministerial position, when a failed coup forced President Moi "to reconsider his cultivated antipathy towards Muslims" (Bakari 2013, 17). During the transition to multi-party elections, the government sought to suppress the nascent Islamic Party of Kenya (IPK) (Aronson 2013; Vittori, Bremmer, and Vittori 2009). ${ }^{7}$ More recently, (Christian) prime minister Raila Odinga's failed collaboration with Muslim constituencies during his presidential run, such as the memorandum of understanding described earlier, fueled skepticism about the possibilities for Muslims' national policy engagement (Elischer 2019). Similarly, Chome's interviews with Muslim activists revealed 
that debates over the inclusion of Kadi courts in the 2010 constitution, coupled with the experience of counterterrorism campaigns, contributed to a sense of "Muslim victimization" and heightened skepticism that "Muslim interests could be advanced through formal political processes" (2019, 548).

Diversity among Kenya's Muslims also poses challenges to political organizing. For Ndzovu (2014), internal ethnic and racial divides have weakened mobilization, despite a shared sense of marginalization. Elischer (2019) argues that the geographic distance between Nairobi and the Muslim-majority Coast and Northeast regions further marginalizes Muslims in national politics. As Kresse (2009) writes,

For coastal Muslims, life on the Kenyan periphery-vis-à-vis a state governed and administered by upcountry Christiansreflects the continuation of historical tensions between coast and upcountry (pwani and bara) which has also involved channels of serfdom and slavery (utumwa). (578)

In contrast, Christian churches have a long history of direct political engagement in Kenya. During one-party rule, the Anglican Church, the Catholic Church, and the Presbyterian Church of East Africa pushed for a democratic transition (Sabar-Friedman 1997). More recently, Christian groups have been highly active on issues of sexuality and gender. Renewalist (i.e., Pentecostal and Charismatic) churches were key in pushing anti-LGBT policy across Africa, leveraging their mobilizational capacity to influence politicians (Dreier 2018; Grossman 2015). In 2019, Kenya's Christian leaders rallied with Muslim leaders to thwart decriminalization of homosexual sex, and Kenya's Supreme Court upheld the law in May 2019 (Ndiso 2019). ${ }^{8}$

This section has introduced the context in which our explanatory variable of interest-marginalization-is rooted. Muslims in Kenya perceive their position as one of marginalization, enduring from the colonial era to present day. We anticipate that membership in community institutions that perceive themselves as subject to "historical, current and structural marginalisation" (as cited at the start of this section) transforms how citizens see their own ability to impact change. Our central hypothesis is that

Muslims in Kenya will report lower perceptions of environmental efficacy due to their marginalized position within the state.

By studying a multi-ethnic religious group, we also gain insight into the potential impacts of ethnicity and religious doctrine on environmental efficacy. In the Kenyan context, much has been written about ethnicity, which politicians instrumentalize to drum up political support (Khadiagala 2019; Oyugi 1997). However, we stress that marginalization is conceptually distinct from ethnic favoritism or disfavoritism, which changes with election cycles and shifting coalitions of power. We would not expect disfavoritism to have the same impact on efficacy as marginalization, which is structural and ongoing. 9 In centering religion, we join new work such as McClendon and Riedl (2019), Sperber and Hern (2018), and McCauley (2014) to stress the salience of religious identities in African politics; unlike these scholars, we foreground marginalization as the mechanism explaining religious impacts, rather than doctrine or practice.

Muslims' attitudes toward the state and religious institutions provide further insight into the relationship between marginalization and efficacy. If marginalization impacts Muslims' sense of environmental efficacy, we should see that general expressions of trust towards state actors condition the relationship between religion and efficacy. Similarly, if narratives within community institutions dampen efficacy, we would anticipate conditional effects of trust in religious leaders. In the following analyses, we examine expressions of trust in state and religious leaders as additional evidence of the relationship between marginalization, institutions, and environmental efficacy.

\section{Methods and Data: Interviews, Focus Groups, and Surveys}

We draw on qualitative and quantitative data to explore whether membership in marginalized community institutions impacts efficacy in the Kenyan context. Our key outcome of interest is citizens' efficacy in relation to climate change, which we term "environmental efficacy." While our theory draws on the concept of political efficacy more broadly, this measure exclusively captures one high salience political issue: climate change.

Our qualitative data come from exploratory fieldwork that examines how religious congregations and leaders discuss climate change, its causes and solutions, and their ability to respond to it. We conducted sixteen interviews with imams, priests, and pastors and nine focus groups with seventy-nine congregants in 2018. ${ }^{10}$ Interviews and focus groups were conducted in English or Swahili (with the help of a translator), recorded, and transcribed. Each transcript was then coded for key themes, using a combination of a deductive coding guide and inductive identification of key subtopics within larger topics. The questionnaire focused on religious groups' responses to climate change and did not prompt for experiences of marginalization.

Congregations were selected at three sites, capturing varying levels of urbanization, socioeconomic status, and religious demographics. It was important to include both urban and rural field sites, as experiences of climate change and religious dynamics vary between urban and rural areas. Within the capital, we selected two sites to capture socioeconomic variation: Central Nairobi and Dandora. Our Central Nairobi sample includes the middle-class neighborhoods or "estates" of Westlands and Kileleshwa. Dandora is a poor, densely populated settlement on the outskirts of Nairobi County, home to Nairobi's largest landfill. Our third site is the county of 
Kilifi, a rural and predominantly Muslim county in the former Coast Province area, complementing the Christian majority demographics of the other two field sites. ${ }^{11}$ Refer to the online appendix for further details on the qualitative data collection.

Our quantitative analysis relies on the Round 7 Afrobarometer survey of 1,599 Kenyans in 2016. The Afrobarometer is the only nationally representative survey administered in many African countries that includes information on political attitudes, behaviors, and demographics. Our reliance on this questionnaire limits our ability to fully measure some key concepts of interest. For instance, this round does not include questions that disaggregate internal and external efficacy, nor can we explore Sunni versus Shi'a religious affiliation or membership in certain Christian denominations. However, as described earlier, scholars have convincingly argued that Muslims widely share the experience of marginalization in Kenya. For the first investigation of whether membership in marginalized community institutions impacts efficacy in the Kenyan context, the Afrobarometer provides meaningful insights.

Our main outcome variable, environmental efficacy, comes from a multistage question about climate change. First, interviewers asked, "Do you think that climate change needs to be stopped?" Of respondents receiving the question, $21 \%$ said that climate change did not need to be stopped, and another $9 \%$ of responses were missing/ don't know. ${ }^{12}$ Second, the remaining $70 \%$ who thought climate change should be stopped were asked, "How much do you think that ordinary Kenyans can do to stop climate change?" Response options were that "ordinary Kenyans" could "do nothing at all," "do a little bit," and "do a lot." We recode responses to create an ordinal variable in which "nothing" is 0 , "a little" is 1 , and "a lot" is 2 . We rely on these attitudes about the agency of "ordinary Kenyans" as our measure of environmental efficacy. Refer to the online appendix for additional information on variable coding.

\section{Results}

\section{Religious Identity and Environmental Efficacy}

Overall, Afrobarometer respondents in Kenya felt empowered to address climate change. Among those who said that climate change should be stopped, only $19 \%$ believed that ordinary citizens could do "nothing at all," while $46 \%$ were optimistic that ordinary citizens could do "a lot." As we show in the online appendix, Kenyans are among the most environmentally efficacious citizens on the African continent. This sense of efficacy is the outcome of interest in the analyses that follow.

Figure 1 examines agency beliefs across religious groups. ${ }^{13}$ In multivariate analysis, non-religious and Christian respondents are predicted to have identical levels of agency: nearly half said that ordinary Kenyans could do a lot to impact climate change, and about one-third thought they could do nothing. Muslims, however, stand out from other groups. In bivariate analysis without controls, only $13 \%$ of Muslim respondents reported high agency in relation to climate change, and nearly half $(48 \%)$ said they could do nothing. Some of this gap, however, is due to covarying traits such as education and rural residence; as figure 1 shows, the gap is smaller in multivariate analysis. Still, even after controlling for a wide range of demographics, Muslims are predicted to be twice as likely as other groups to say that they could do "nothing" about climate change, and half as likely to say that they could do "a lot."

The remainder of the paper seeks to explain this difference. First, we present evidence that Muslim leaders and congregants are more likely to describe an unresponsive state than members of other major religious institutions in Kenya. Second, we show that citizens' relationships with the state and religious leaders condition their sense of agency-but only among Muslims. In the final three sub-sections, we consider a series of other possible explanations: that religious differences are a spurious result of ethnicity or pastoralism, or that differences in Muslims' beliefs about the causes of climate change or their attitudes about its salience explain Muslims' lower efficacy. However, none of the alternative explanations adequately explains the efficacy gap.

\section{Narratives of State Marginalization and Efficacy}

Perceived oppression and state neglect, we argue, erode Kenyan Muslims' sense of environmental efficacy, as individuals rationally expect the state to stymie their activism. Our Muslim focus group participants eloquently expressed this view. While many saw politicians as deliberately indifferent to their problems, describing them as "elusive," "not dependable," and there for "their own benefits," others referenced active hostility to collective action. One respondent supported his claim that state actors could not be relied upon to address climate change by alluding to a recent protest, saying "they go and throw tear-gas on kids that are studying ... so it means the politicians cannot help."

Moreover, Muslims experience marginalization not simply as atomized individuals. Instead, religious communities internally communicate, disseminate, and reinforce members' senses of marginalization, as well as their perceptions of the likely inefficacy of potential mobilization. Every Muslim leader we interviewed expressed alienation and distance from politicians; this was a constant across ethnic groups and locations in urban Nairobi or rural Kilifi. As one imam explained, "when you see politicians, it is when they are campaigning, they are looking for votes, but about your lifestyles, about what is affecting your safety, they are not there and they will never be there, not in Kenya." Another imam reported that: 


\section{Figure 1}

\section{Environmental efficacy, by religious affiliation}

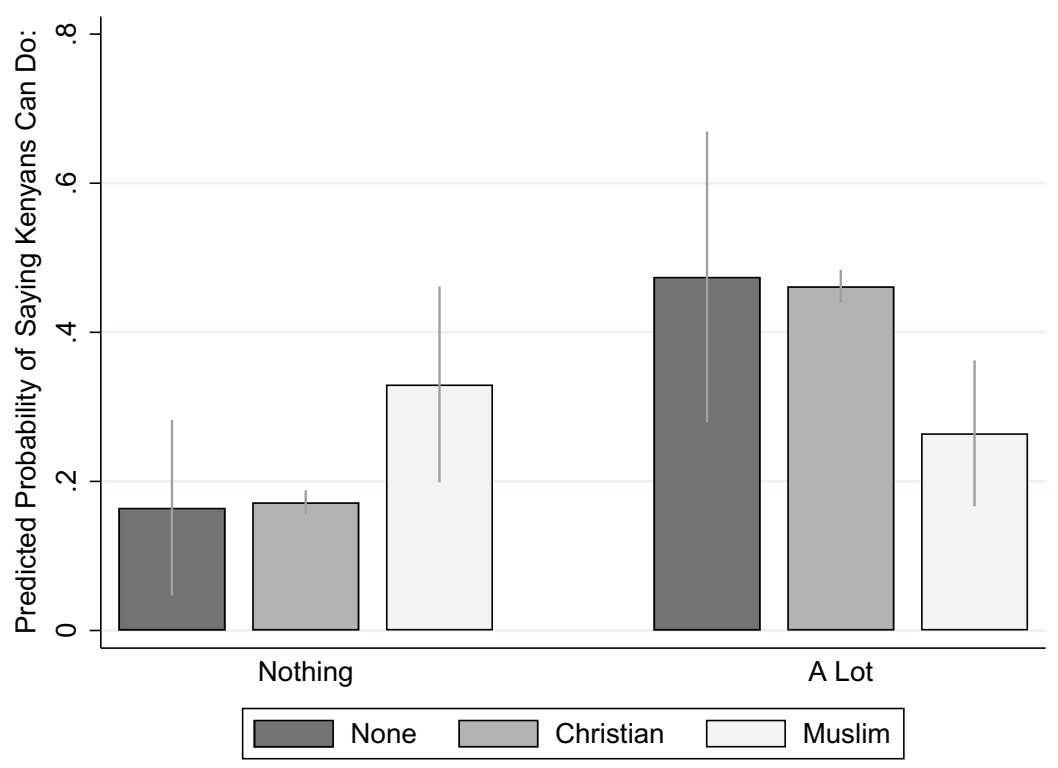

Note: 90\% confidence intervals shown; estimates from Model 1. Source: Afrobarometer Round 7, 2016.

The ways in which we are able to communicate to them becomes a problem ... because most of the time finding them is not easy and most of the time there is a very big gap between the political and religious leaders except for the time they need prayers only; when someone wants to be sworn in as president you are called to pray for them but other times you can't find them. Politicians, we can use them only the time when they come to the church or mosque.

Catholic and Pentecostal leaders expressed comparatively strong ties to politicians. In direct contrast with the imam who described the difficulty of contacting politicians, a Pentecostal pastor in Dandora reported that "we have our MCA [Member of County Assembly] here, so approaching him is not difficult since he is in the area. Even their bouncers when you meet them you can tell them so that they take the message to him/her." A pastor in rural Kilifi explained,

You see the church as an organization is not just independent, it works in the nations and in the countries where the governments do also work. So the church has a percentage of contribution to help the community to have good life and the government is also concerned in the provision of good life of the community, so what I think is that it's good that they work hand in hand.

As these quotes hint, differing access to the state appeared to affect the perceived feasibility of environmental action. In our interviews, Christian clergy reported organizing activism and contacting politicians. One Catholic leader had recently convened a dinner bringing local chiefs, county assembly members, and other politicians together to discuss how to address the local dumpsite.
Several priests thought that the church was an influential partner with the government in addressing climate change. Similarly, Pentecostal leaders described initiatives and workshops coordinating religious groups, NGOs, and government entities to address the issue. Christian leaders in the heavily Muslim (and geographically peripheral) Kilifi area expressed similarly high linkages to state politicians as those based in the capital city.

Historical discrimination and exclusion appear to inhibit such activities among Muslims. All clergy, including imams, said they talked about climate change with congregants. For example, one imam reported using "words of urgency" to discuss environmental issues in sermons. Another imam explained that "we should not wait for another Wangari Maathai, actually everybody should be Wangari Maathai, we should do everything and we should pray as well." However, Muslim focus group participants were less likely than members of other groups to believe the government would respond. For example, "there are challenges as our discussions are not getting any support from the government, both national and county, yet they are supposed to be the implementers." A second participant complained that "our religious leaders talk often about these changes but they too get to a point they still need the implementers, the government. So we go back to depending on the government." While Muslims saw the government as necessary for climate change solutions, such that "the common citizen can't do anything because there is a stage he gets to where it is the responsibility of the government," 
others expressed the futility of a state response: "we should not bother ourselves with engaging politicians."

By contrast, respondents in the Christian focus groups articulated far greater expectations that it was possible to collaborate with the government to impact climate change. For example, one Pentecostal congregant argued that "the church should partner with the politicians ... because politicians have a lot of influence in our community and so does the church so with these two coming together then we can work together to make our environment better." One respondent explicitly described her expectations of governmental responsiveness:

I think the government listens to the Catholic Church, I do believe that Catholic Church in a country is like another government so, I think if the Catholic Church decides that their leaders and their priests decide we need to do something to our environment I think our government will listen, our politicians will listen, of which most of our politicians are Catholics. I think through that way it would be easier.

Overall, these interviews revealed that members of different institutions diverged widely in belief that they could effect environmental policy change in connection with state actors.

\section{The Conditioning Effects of Trust on Kenyan Muslims' Efficacy}

Our quantitative analysis provides further evidence supporting the marginalization theory: views of the state and religious leaders help to explain Muslims' lower efficacy. The analysis presented in Model 4 of table 1 and figure 2 reveals that trust in state institutions shapes Kenyan Muslims' sense of their own efficacy to make a difference on climate change. This indicates that the individual's relationship with the state impacts the link between religion and environmental efficacy. This is particularly meaningful evidence in favor of the marginalization argument, given that our measure of environmental efficacy does not prompt for perceptions of governmental responsiveness. ${ }^{14}$ The analysis shows that moving from the minimum to the maximum level of trust in the state raises Muslims' predicted probability of reporting high environmental efficacy from .12 to .45 , and it is associated with a drop in the probability of reporting low efficacy from .54 to .17 . However, attitudes toward the state only matter for Muslims. Group histories of marginalization have made the state salient as a potential limiting force constraining Muslims' political participation. By contrast, environmental efficacy is not linked to state trust in religious groups without a history of marginalization. As a result, the gap in efficacy between Muslim and non-Muslim respondents is limited to citizens who distrust state leaders; there is no efficacy gap among citizens with high trust in state leaders.

Ties to community institutions also affect efficacy within marginalized groups. A series of models in the online appendix show that trust in religious leaders conditions the impact of religious affiliation on efficacy. Muslims who strongly trust their religious leaders report substantially lower efficacy to address climate change than do Muslims who are weakly tied to the hierarchy within their religious communities. In these survey data, we do not have evidence for the mechanism; Muslim leaders might socialize their communities via collective narratives of marginalization that compound feelings of low efficacy, or the types of Muslims who trust religious leaders might have low efficacy. Nonetheless, our qualitative evidence provides strong indications that Muslim communities widely share and discuss a feeling of disconnection from the state that stymies efficacy and activism. Similarly, other scholars observe that Muslim leaders explicitly discourage political engagement in response to marginalization; Chome, for instance, found that some sermons included "religious justifications for Muslim disengagement with the formal political process" (2019, 549).

In Model 5 of table 1 and figure 3, we introduce a measure of the gap between trust in state and in religious leaders. This gap is extremely predictive of environmental efficacy; among Muslims who trust religious leaders much more than state leaders, the predicted likelihood of saying that "nothing" can be done is .75, and that of saying that "a lot" can be done is only .05. Among Muslims who trust state leaders much more than religious leaders, by contrast, the equivalent predicted likelihoods are inverted, at .01 and .92. Such ties have no impact on the attitudes of nonMuslim Kenyans. These results indicate that alienation from the state and ties to community institutions both impact the efficacy of Muslim citizens. ${ }^{15}$

\section{Do Ethnic or Other Identities Explain the Efficacy Gap?}

An alternative explanation is that the correlation between religious affiliation and efficacy might stem from underlying differences among ethnic groups. Ethnicity and religion are intertwined in Kenya; 65\% of Muslims in our Afrobarometer sample are Somali. This ethnic group may well report lower efficacy, given the Kenyan state's responses to al-Shabaab attacks and accusations of "foreignness." 16 Hence, our analysis presented in figure 1 includes indicator variables for identification as Somali or as Masai and Samburu. The latter two ethnic groups were historically semi-nomadic, giving them a unique status within the state that could potentially impact efficacy.

Table 2 in the online appendix presents a series of robustness checks further exploring the role of ethnicity. Model 1 in that table show that Muslims have significantly lower environmental efficacy, even controlling for a long list of other ethnic groups. Model 2 accounts for ethnic grievances, based on a question asking "how often, if ever" the respondent's ethnic group was "treated unfairly by the government"; this control does not significantly change 
Table 1

Determinants of environmental efficacy

\begin{tabular}{|c|c|c|c|c|c|}
\hline & (1) & (2) & (3) & (4) & (5) \\
\hline Muslim & $\begin{array}{r}-0.917^{*} \\
(0.485)\end{array}$ & $\begin{array}{l}-1.130^{* * *} \\
(0.369)\end{array}$ & $\begin{array}{l}-0.967^{\star \star *} \\
(0.352)\end{array}$ & $\begin{array}{l}-1.982^{\star \star \star} \\
(0.563)\end{array}$ & $\begin{array}{c}-0.064 \\
(0.354)\end{array}$ \\
\hline Climate Worsening & - & $\begin{array}{r}-0.123^{*} \\
(0.067)\end{array}$ & $\begin{array}{l}-0.199^{\star \star \star \star} \\
(0.074)\end{array}$ & $\begin{array}{l}-0.201^{\star \star \star} \\
(0.065)\end{array}$ & $\begin{array}{l}-0.195^{\star \star \star} \\
(0.068)\end{array}$ \\
\hline CC Has Human Causes & - & - & $\begin{array}{l}1.143^{\star \star \star} \\
(0.389)\end{array}$ & $\begin{array}{l}1.165^{\star \star \star} \\
(0.398)\end{array}$ & $\begin{array}{l}1.168^{\star \star \star} \\
(0.428)\end{array}$ \\
\hline Trust in State & - & - & - & $\begin{array}{c}-0.094 \\
(0.492)\end{array}$ & - \\
\hline Muslim $\times$ Trust in State & - & - & - & $\begin{array}{l}1.983^{\star \star \star} \\
(0.543)\end{array}$ & - \\
\hline Trust Gap (Religious Leaders v. State) & - & - & - & - & $\begin{array}{c}-0.015 \\
(0.339)\end{array}$ \\
\hline Muslim $\times$ Trust Gap & - & - & - & & $\begin{array}{l}-2.867^{\star * *} \\
(0.990)\end{array}$ \\
\hline Masai/Samburu & $\begin{array}{l}-0.445 \\
(0.305)\end{array}$ & $\begin{array}{c}-0.457 \\
(0.294)\end{array}$ & $\begin{array}{r}-0.599^{*} \\
(0.334)\end{array}$ & $\begin{array}{r}-0.583^{*} \\
(0.339)\end{array}$ & $\begin{array}{r}-0.585^{*} \\
(0.346)\end{array}$ \\
\hline Somali & $\begin{array}{c}0.324 \\
(0.631)\end{array}$ & $\begin{array}{c}0.668 \\
(0.497)\end{array}$ & $\begin{array}{l}0.125 \\
(0.364)\end{array}$ & $\begin{array}{c}-0.382 \\
(0.455)\end{array}$ & $\begin{array}{l}-0.33 \\
(0.393)\end{array}$ \\
\hline Pastoralist & $\begin{array}{l}-0.631^{\star \star \star} \\
(0.209)\end{array}$ & $\begin{array}{l}-0.606^{\star \star \star} \\
(0.201)\end{array}$ & $\begin{array}{l}-0.644^{\star *} \\
(0.270)\end{array}$ & $\begin{array}{l}-0.648^{* *} \\
(0.265)\end{array}$ & $\begin{array}{l}-0.668^{\star *} \\
(0.262)\end{array}$ \\
\hline Education & $\begin{array}{r}0.126^{\star} \\
(0.076)\end{array}$ & $\begin{array}{l}0.119^{*} \\
(0.072)\end{array}$ & $\begin{array}{l}0.085 \\
(0.064)\end{array}$ & $\begin{array}{c}0.083 \\
(0.063)\end{array}$ & $\begin{array}{l}0.086 \\
(0.065)\end{array}$ \\
\hline Age & $\begin{array}{c}0.002 \\
(0.006)\end{array}$ & $\begin{array}{c}0.001 \\
(0.005)\end{array}$ & $\begin{array}{c}0.002 \\
(0.005)\end{array}$ & $\begin{array}{c}0.002 \\
(0.005)\end{array}$ & $\begin{array}{c}0.001 \\
(0.005)\end{array}$ \\
\hline Urban & $\begin{array}{c}0.092 \\
(0.134)\end{array}$ & $\begin{array}{c}0.101 \\
(0.141)\end{array}$ & $\begin{array}{c}0.091 \\
(0.159)\end{array}$ & $\begin{array}{l}0.108 \\
(0.146)\end{array}$ & $\begin{array}{l}0.137 \\
(0.119)\end{array}$ \\
\hline Food scarcity & $\begin{array}{l}-0.139 \\
(0.095)\end{array}$ & $\begin{array}{l}-0.126 \\
(0.094)\end{array}$ & $\begin{array}{r}-0.133 \\
(0.091)\end{array}$ & $\begin{array}{l}-0.13 \\
(0.097)\end{array}$ & $\begin{array}{l}-0.133 \\
(0.095)\end{array}$ \\
\hline Male & $\begin{array}{c}0.021 \\
(0.165)\end{array}$ & $\begin{array}{c}0.033 \\
(0.161)\end{array}$ & $\begin{array}{c}0.075 \\
(0.179)\end{array}$ & $\begin{array}{l}0.07 \\
(0.179)\end{array}$ & $\begin{array}{c}0.084 \\
(0.179)\end{array}$ \\
\hline Observations & 743 & 730 & 718 & 718 & 710 \\
\hline
\end{tabular}

Notes: Results from ordinal logistic regression models clustered on region. Regional fixed effects and logistic regression cutpoints not shown; standard errors in parentheses. ${ }^{*} p<.10,{ }^{* \star} p<.05,{ }^{\star \star \star} p<.01$

Source: Afrobarometer Round 7, 2016

the effect of Muslim on efficacy. Finally, Model 3 adds an ethnic salience variable to the baseline model as a third check for a potentially confounding impact of ethnicity, based on a question asking whether the respondent would identify as Kenyan or a member of their ethnic group if they "had to choose." All three models increase our confidence that something about Muslims' experiences in Kenya reduces their efficacy, independently of ethnicity.

Our qualitative data support the conclusion that the association between religion and environmental efficacy is not simply a spurious result of ethnicity. In our rural Kilifi sample, respondents from the same ethnic group (Mijikenda) but different religious communities (Pentecostal and Mus$\mathrm{lim}$ ) expressed markedly distinct expectations of responsiveness from politicians. The two Pentecostal pastors both described collaborative relationships with the state. One detailed a joint effort in which the church mobilizes labor for an environmental campaign funded by the government. In stark contrast, Muslim leaders and congregants could not envisage such collaboration. As one imam in Kilifi put it succinctly: "No politician will listen to you." In Central Nairobi and Dandora, our Muslim focus groups were ethnically mixed, including a small number of ethnic-Somalis, yet there were no systematic differences in expectations of government responsiveness and environmental efficacy across the Muslim samples. The qualitative data reveal that Muslims share the perception of a non-responsive state; it is not unique to any ethnic group or region.

Our models also consider the role of pastoralism. Pastoralists are highly exposed to climate change, as decreases in water and viable grazing land force them to move to provide for livestock. Analysis in the online appendix shows that pastoralists are significantly more concerned about climate change than other groups. Moreover, in Kenya and globally, pastoralists have had contentious relationships with the state, and a semi-nomadic livelihood inhibits organizing (Azarya 1996; Kituyi 1985). For all these reasons, it is little surprise that pastoralists express significantly lower environmental efficacy than other groups (refer to table 1). However, 


\section{Figure 2}

\section{Trust in state leaders boosts environmental efficacy among Muslims}

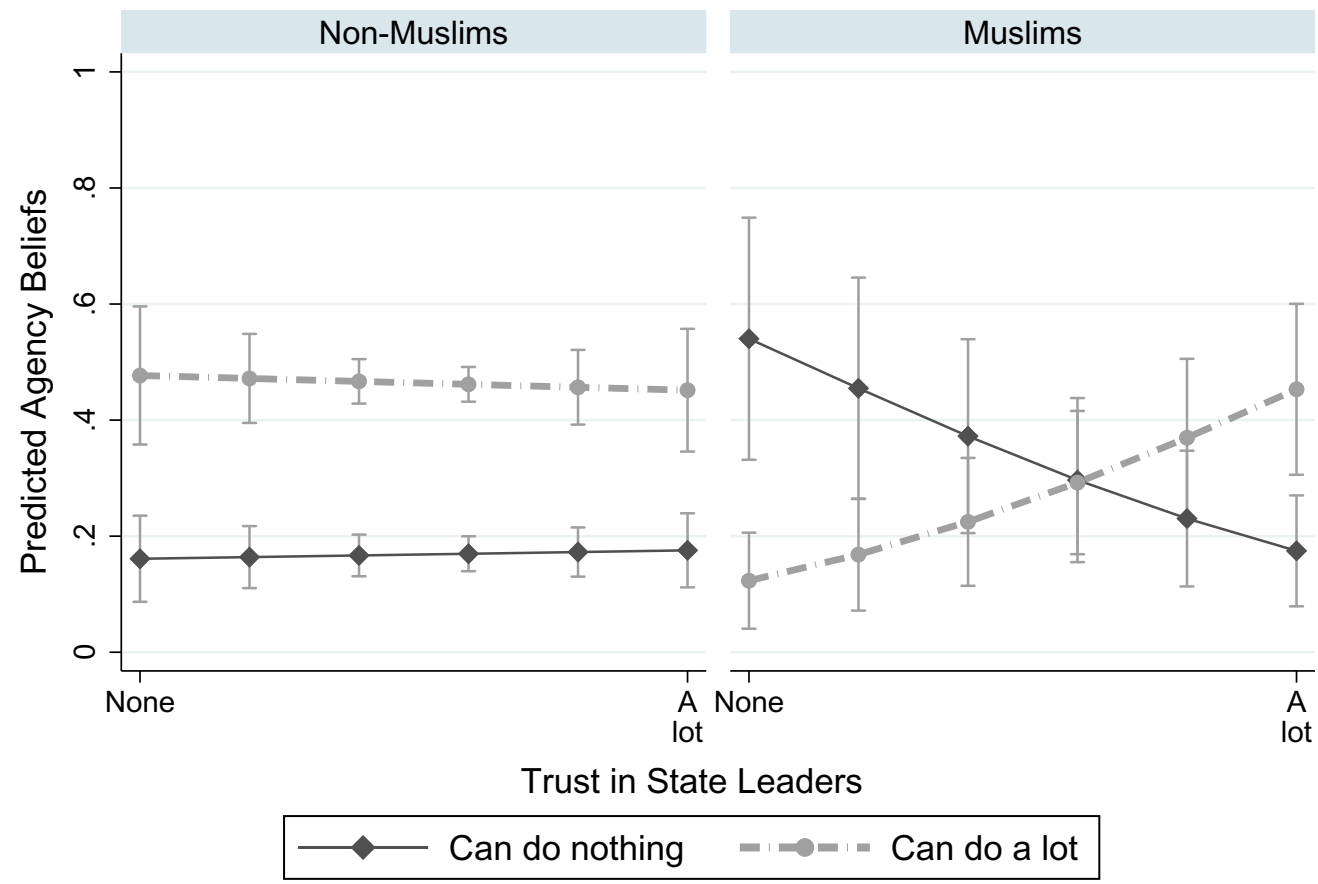

Source: Afrobarometer Round 7, 2016

pastoralism does not explain the significant effect of Muslim affiliation on efficacy.

\section{Do Beliefs about the Causes of Climate Change Explain the Efficacy Gap?}

A second alternative explanation for religious differences in environmental efficacy relates to doctrinally rooted scientific beliefs. The question of whether climate change is anthropogenic or instead results from natural_or even supernatural-processes is a central divide in public opinion on the environment. It stands to reason that people would be skeptical of their power to solve a problem perceived as natural or divine in origin. Religious teachings contain wide-ranging propositions about the nature of the material world, and the role of supernatural forces in the weather. It seems plausible that Kenyan Muslims might share ontological approaches to humans' role in climate change-beliefs that influence perceptions of environmental agency.

However, we find little evidence of such religious differences. In the Afrobarometer, 61\% of respondents saw human behavior as the sole cause of climate change, and another $14 \%$ attributed climate change to both human and natural causes; just 25\% attributed it to natural processes or other factors. There are no statistically significant differences between Christians, Muslims, and the non-religious in such beliefs (refer to the online appendix). ${ }^{17}$ Qualitative fieldwork confirms the absence of religious differences in causal attributions. Across religious groups, clergy provided strikingly consistent explanations of climate change. Every leader interviewed reported that changing weather resulted from human behavior, including phenomena such as charcoal burning, deforestation, and air pollution. Some clergy did also reference more distal behaviors, such as lack of prayer; sexual sin and deforestation were discussed together seamlessly, as joint causal factors. As one imam described, "the teachings of science and religion are not far off, I think they relate closely." In addition, none of the clergy thought climate change was a result of a natural process of change over time.

In sum, religious differences in causal attributions are small and cannot explain differing environmental agency across religious groups. Indeed, controlling for the perception that climate change is anthropogenic in our model of efficacy does not reduce the size or the statistical significance of Muslim religious affiliation-despite the fact that belief in the human origin of climate change is, as we speculated, a highly statistically significant predictor of efficacy (refer to table 1, model 3). Belief that climate change is anthropogenic raises the predicted probability of reporting high environmental efficacy from .26 to .50 . 


\section{Figure 3}

\section{The gap in trust between religious and state leaders reduces environmental efficacy among Muslims}

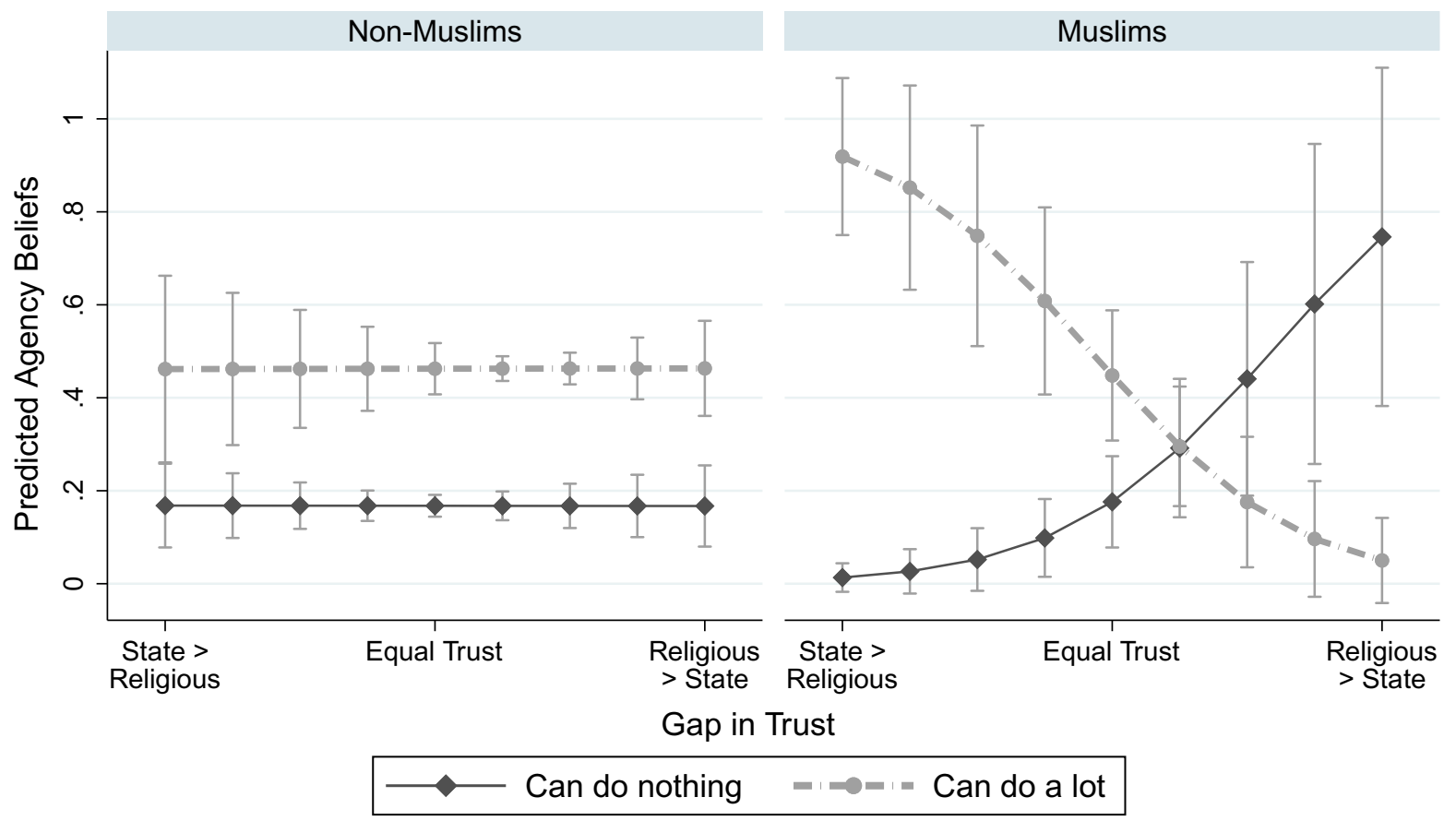

Source: Afrobarometer Round 7, 2016

\section{Does Issue Salience Explain the Efficacy Gap?}

Climate change might affect Muslims more severely than members of other groups-perhaps due to Muslims' concentration in certain geographic areas, or in certain occupations. Actually experiencing climate change might sap one's sense of efficacy. However, empirical analysis reveals two key findings. First, after controlling for differences in region and material circumstances, there are no interreligious differences in issue salience. Second, controlling for issue salience increases the estimated Muslim/ non-Muslim gap in environmental efficacy.

In general, Kenyans are quite concerned about climate change. In 2016, 56\% of the sample reported that the climate had gotten worse in the past decade. In addition, $15 \%$ mentioned a climate-related issue as the most important problem for the government to address, and $38 \%$ mentioned it as one of the three most important problems. In qualitative interviews, religious leaders unanimously agreed, as did participants in eight of nine focus groups, that the weather was changing, interpreted as part of a broader pattern. ${ }^{18}$ They supported their beliefs with examples of extreme weather and environmental changes, including unpredictable rainy seasons and extreme temperatures, drought, flooding, and decreases in harvests and fish stocks.
In a bivariate analysis of the Afrobarometer, environmental concern is higher among Muslims than other groups. However, this appears entirely to be the result of covarying traits. Kenyan Muslims cluster in the Northeast and Coast provinces, which have been highly affected by severe weather. For example, a drought in 2005-2006 caused a $70 \%$ decrease in the size of herds in Northern Kenya, leading pastoralists, including many Muslims, to become heavily reliant on international aid (Baird 2008, 4). In addition, Muslim religious affiliation is correlated with formal education, poverty, and rural livelihoods—all of which may impact issue salience. In multivariate models, religious affiliation is uncorrelated with both environmental concern and belief that climate change needs to be stopped (refer to the online appendix); religious differences are due entirely to Muslims' concentration in regions highly affected by climate change.

Model 2 in table 1 considers the relationship between religious affiliation and efficacy, controlling for beliefs that the climate is worsening. Strikingly, after we account for the salience of climate change, the gap in efficacy between Muslims and non-Muslims grows. The predicted gap in saying that "ordinary Kenyans" can do nothing widens to 21 percentage points, and the gap in saying that they can do a lot widens to 24 percentage points. Different 
perceptions of the changing climate are not the source of lower efficacy among Muslims in Kenya. Instead, the qualitative and quantitative data indicate that marginalization generates systematic differences in how members of religious institutions evaluate their ability to impact climate change.

\section{Discussion and Conclusions}

Efficacy links interests to action-yet poor treatment by the state severs that link. Policies marginalizing communities thus impact political engagement over the long term. However, these effects are not automatic; community institutions shape the relationship between marginalization and agency. Though theories of political efficacy tend to treat social networks as a resource that boosts efficacy, networks reinforcing narratives of marginalization should yield the opposite outcome.

Insights gleaned from interviews in Kenya elucidate the argument: Muslim community institutions reinforced a narrative of members' incapacity to effect change. Leaders emphasized that politicians would not respond to their demands, rendering collective action for policy change ineffective; congregants echoed those assessments. Thus, focus groups with Muslims captured pieces of a continuing conversation within the community about discrimination and the limits of agency. By contrast, while it would be a grave mistake to suggest that non-Muslim Kenyans are highly trusting of state institutions, leaders and members of Christian community institutions expressed systematically higher expectations of state responsiveness than did Muslims.

Quantitative analysis bolsters our conclusions. Muslim citizens expressed lower efficacy than other groups-a relationship that cannot be attributed to differences in education, wealth, ethnicity, or region, nor to issue salience or beliefs about the causes of climate change. Instead, Muslims' reduced efficacy is a function of their relationships to the state and religious leaders. That the conditional effects are unique to Muslims suggests the importance of community institutions as a forum where marginalized citizens learn what to expect of the state. Despite a vast literature on collective identity and political behavior in Africa, this is, to our knowledge, the first empirical study of collective marginalization and efficacy in the African context.

These findings also have implications for climate change policy. First-in striking contrast with the United States (Guth et al. 1995)—we find no religious differences in climate change beliefs in Kenya. Nearly all religious leaders and focus group respondents thought that climate change was an important issue, one with human causes and solutions. After accounting for regional differences, religious groups prioritized climate change equally. Our results echo work elsewhere that uncovers no religious differences in these beliefs in Latin America (Smith and Veldman 2020). Moreover, the findings are consistent with studies that identify climate change as a high priority among Muslims in Turkey, Indonesia, the Palestinian territories, and Nigeria (Lewis, Palm, and Feng 2019). Yet in other contexts, membership in Muslim religious institutions may actually increase environmental efficacy (e.g., Amri 2013). Against the backdrop of prior findings, our results indicate that a religious institution's relationship with state and political power-a product of a specific political context-is highly consequential for citizen climate activism.

Second, our analysis suggests that groups that are highly concerned about climate change may remain on the sidelines due to experiences of marginalization. Crossnationally, countries that are most affected by climate change are also least able to prevent it. This study demonstrates a similar phenomenon on a sub-national level: respondents for whom climate change was most salient felt least efficacious addressing it. In addition to the Muslim minority, we also observe this result in the plight of pastoralists, who are highly impacted by drought and climate instability, but were significantly less likely than other respondents to say that they could effect change. If the most vulnerable populations are less likely to organize collective action, climate change policy is unlikely to respond to their specific needs. This further reinforces their real and perceived exclusion from the processes of addressing climate change. Consequently, these findings provide a lesson to policymakers: in designing climate change policy, it is critical to identify citizens who may be systematically less likely to engage. Mitigating climate change requires mitigating the effects of marginalization.

\section{Supplemental Materials}

1. Environmental Efficacy in Kenya in Comparative Context

2. Qualitative Research Design

3. Variable Coding for the Afrobarometer Analysis

4. Robustness Checks and Additional Statistical Analyses To view supplementary material for this article, please visit http://dx.doi.org/10.1017/S153759272000479X.

\section{Acknowledgements}

Thanks to Paul Djupe, Calla Hummel, Ned Littlefield, John McCauley, Liz Sperber, Scott Strauss, seminar participants at the University of Wisconsin, Madison, audiences at the 2019 American Political Science Association and African Studies Association Annual Meetings, and anonymous reviewers for both Perspectives on Politics and the Kellogg Institute's Working Paper Series for helpful comments on prior versions of this paper. Mercy Ngao and Melda Munyazi provided excellent research assistance in Kenya. The British Institute in Eastern Africa provided institutional support. This research was funded by a Project Launch Grant from the Global Religion Research 
Initiative of the University of Notre Dame. The research was reviewed by the IRBs of Iowa State University and Boston College, and was cleared by the National Commission for Science, Technology \& Innovation in Kenya.

\section{Notes}

1 While psychologists identify efficacy as the source driving human agency (Bandura 2000), we use "efficacy" and "agency" interchangeably.

2 Scholarship on citizens' perceived ability to impact environmental outcomes and policy variously uses the terms "environmental efficacy," "environmental locus of control," and "response efficacy." Despite nuances among these terms, we group all of these concepts under the umbrella of "environmental efficacy."

3 These orientations are not static; descriptive representation increases African Americans' sense of trust and external efficacy (e.g., West 2017; Bobo and Gilliam 1990).

4 We coded articles that appeared on a randomly selected day each week in the six months leading up to elections, to capture climate change discourse.

5 Refer to Appendix B of Ndzovu (2014) for a copy of the signed document.

6 According to the U.S. Department of State (2018), approximately $80 \%$ of Kenyans are Christian: $48 \%$ mainline Protestant, 23\% Catholic, and 12\% Evangelical/Pentecostal. A further 4\%-5\% subscribe exclusively to indigenous religions. Though most Kenyan Muslims are Sunni, there are also Shi'a and Abadi populations; Ndzovu 2014, 8.

7 Chome argues that the IPK's failure led to a proliferation of Muslim organizations "seeking to mobilize the Muslim voice in Kenya"; 2019, 542.

8 Kenyan Muslims are not politically passive. Muslims protested to demand the withdrawal of U.S. counterterrorism agents (Mogire and Mkutu Agade 2011) and oppose the extradition of Kenyan nationals accused of terrorism (Vittori et al. 2009, 1084). In the early 2000s, Muslims protested the Equality Bill, perceived as encroaching on Islamic law (Ndzovu 2014, 108). However, in comparison to Christian institutions' history of policy negotiation with the Kenyan state, Muslims have been less successful.

9 For example, Ross 1975 finds no differences in political efficacy among competing ethnic groups in Nairobi.

10 Focus groups were composed of male and female congregants at the sampled mosque or church. Participants were invited with the knowledge and consent of community leaders. The groups varied in size from six to eleven participants.

11 This sample does not include majority ethnic Somali communities in the Northeast, but ethnic Somali respondents were present in Muslim congregations in the Nairobi samples.

12 This item (Q78) was asked only of the 64\% of respondents who previously reported having heard of "climate change." In the online appendix, we explore potential biases in the sample receiving the efficacy question; education predicts receiving the question, but we find no religious biases.

13 The figure presents predicted probabilities from an ordinal logistic regression model controlling for a range of demographics (see Model 1 of table 1 ). Because there are no statistically significant differences among different Christian groups, all Christians are aggregated into one category. All analyses use Afrobarometer's withinwt weight.

14 The online appendix presents models using an alternative index of external political efficacy, measured as perceived ability to elicit a response from government agencies; that index strongly conditions the relationship between Muslim religious affiliation and environmental efficacy.

15 The online appendix presents a number of alternative specifications, all confirming the conclusion.

16 In addition, 26\% of Muslims in the Afrobarometer sample are Mijikenda, a religiously-mixed identity aggregating small, related ethnic groups. Small numbers of Muslim respondents are from the Kikuyu, Luhya, Kamba, Meru/Embu, Taita, Pokot, and Turkana ethnic groups. No respondent identified as ethnically Swahili or Arab.

17 Disaggregating by variety of Christianity, Protestants are significantly more likely than Muslims to report human agency as a cause in multivariate analysis. However, the effects are small; the difference between Muslims and Protestants in the predicted probability of believing humans drive climate change is just .08 (.71 versus .79). No other differences between religious groups were statistically significant in multivariate analysis. A difference of this magnitude could not fully explain the much larger difference in environmental efficacy among religious groups.

18 The exception was one respondent in the Pentecostal focus group in Kilifi.

\section{References}

Abramson, Paul R. 1972. "Political Efficacy and Political Trust among Black Schoolchildren: Two

Explanations." Journal of Politics 34(4): 1243-75.

Afrobarometer. 2016. "Afrobarometer Data, Kenya

Round 7.” (http://afrobarometer.org).

Ahn, Sun Joo (Grace), Jesse Fox, Katherine R. Dale, and J. Adam Avant. 2015. "Framing Virtual Experiences: Effects on Environmental Efficacy and Behavior Over Time." Communication Research 42(6): 839-63. 
Amri, Ulil. 2013. "From Theology to a Praxis of 'Eco-Jihad': The Role of Religious Civil Society Organizations in Combating Climate Change in Indonesia." In How the World's Religions Are Responding to Climate Change: Social Scientific Investigations, ed. Robin Globus Veldman, Andrew Szasz, and Randolph Haluza-DeLay, 75-93. London: Routledge. Arbuckle, Matthew B., and David M. Konisky. 2015. "The Role of Religion in Environmental Attitudes." Social Science Quarterly 96(5): 1244-63.

Aronson, Samuel L. 2013. "Kenya and the Global War on Terror: Neglecting History and Geopolitics in Approaches to Counterterrorism." African Journal of Criminology and Justice Studies (AJCJS) 7(1-2): 24ff.

Azarya, Victor. 1996. "Pastoralism and the State in Africa: Marginality or Incorporation?” Nomadic Peoples 38: 11-36.

Baird, Rachel. 2008. "The Impact of Climate Change on Minorities and Indigenous Peoples." London: Minority Rights Group International. (https://minorityrights. org/wp-content/uploads/old-site-downloads/ download-524-The-Impact-of-Climate-Change-onMinorities-and-Indigenous-Peoples.pdf).

Bakari, Mohamed. 2013. "A Place at the Table: The Political Integration of Muslims in Kenya, 19632007." Islamic Africa 4(1): 15-48.

Balch, George I. 1974. "Multiple Indicators in Survey Research: The Concept 'Sense of Political Efficacy."' Political Methodology 1(2): 1-43.

Bandura, Albert. 2000. "Exercise of Human Agency through Collective Efficacy." Current Directions in Psychological Science 9(3): 75-78.

Barkan, Joel D. 2004. "Kenya after Moi." Foreign Affairs 83(1): 87-100.

Beaumont, Elizabeth. 2011. "Promoting Political Agency, Addressing Political Inequality: A Multilevel Model of Internal Political Efficacy." Journal of Politics 73(1): 216-31.

Bleck, Jaimie. 2015. Education and Empowered Citizenship in Mali. Baltimore: Johns Hopkins University Press.

Bobo, Lawrence, and Franklin D. Gilliam. 1990. "Race, Sociopolitical Participation, and Black Empowerment." American Political Science Review 84(2): 377-93.

Bowler, Shaun, and Todd Donovan. 2002. "Democracy, Institutions and Attitudes about Citizen Influence on Government." British Journal of Political Science 32(2): 371-90.

Brady, Henry E., Sidney Verba, and Kay Lehman Schlozman. 1995. "Beyond SES: A Resource Model of Political Participation." American Political Science Review 89(2): 271-94.

Case, Andrew D., and Carla D. Hunter. 2012. "Counterspaces: A Unit of Analysis for Understanding the Role of Settings in Marginalized Individuals'
Adaptive Responses to Oppression." American Journal of Community Psychology 50(1-2): 257-70.

Chamberlain, Adam. 2012. "A Time-Series Analysis of External Efficacy.” Public Opinion Quarterly 76(1): 117-30.

Chome, Ngala. 2019. "From Islamic Reform to Muslim Activism: The Evolution of an Islamist Ideology in Kenya." African Affairs 118(472): 531-52.

Cleveland, Mark, Maria Kalamas, and Michel Laroche. 2005. "Shades of Green: Linking Environmental Locus of Control and Pro-Environmental Behaviors." Journal of Consumer Marketing 22(4): 198-212.

Coleman, Kenneth M., and Charles L. Davis. 1976. "The Structural Context of Politics and Dimensions of Regime Performance: Their Importance for the Comparative Study of Political Efficacy." Comparative Political Studies 9(2): 189-206.

Croke, Kevin, Guy Grossman, Horacio A. Larreguy, and John Marshall. 2016. "Deliberate Disengagement: How Education Can Decrease Political Participation in Electoral Authoritarian Regimes." American Political Science Review 110(3): 579-600.

Cussac, Anne, and Nathalie Goms. 2010. "Muslims in Nairobi." In Nairobi Today: The Paradox of a

Fragmented City, ed. Deyssi Rodriguez-Torres and Helene Charton-Bigot, 269-286. Oxford: African Books Collective.

Dreier, Sarah K. 2018. "Resisting Rights to Renounce Imperialism: East African Churches' Strategic Symbolic Resistance to LGBTQ Inclusion." International Studies Quarterly 62(2): 423-36.

Elischer, Sebastian. 2019. "Partisan Politics Was Making People Angry: The Rise and Fall of Political Salafism in Kenya." Journal of the Middle East and Africa 10(2): 121-36.

Finkel, Steven E. 1985. "Reciprocal Effects of Participation and Political Efficacy: A Panel Analysis." American Journal of Political Science 29(4): 891-913. 2003. "Can Democracy Be Taught?" Journal of Democracy 14(4): 137-51.

Finkel, Steven E., and Amy E. Smith. 2011. "Civic Education, Political Discussion, and the Social Transmission of Democratic Knowledge and Values in a New Democracy: Kenya 2002." American Journal of Political Science 55(2): 417-35.

Friedman, Willa, Michael Kremer, Edward Miguel, and Rebecca Thornton. 2016. "Education as Liberation?" Economica 83(329): 1-30.

Grossman, Guy. 2015. "Renewalist Christianity and the political saliency of LGBTs: Theory and evidence from Sub-Saharan Africa." Journal of Politics 77(2): 337-51.

Guth, James L., John C. Green, Lyman A. Kellstedt, and Corwin E. Smidt. 1995. "Faith and the Environment: Religious Beliefs and Attitudes on Environmental 
Policy." American Journal of Political Science 39(2): 364-82.

Hadden, Jennifer. 2015. Networks in Contention. New York: Cambridge University Press.

Hern, Erin. 2019. Developing States, Shaping Citizenship: Service Delivery and Political Participation in Zambia. Anne Arbor: University of Michigan Press.

Hines, Jody M., Harold R. Hungerford, and Audrey N. Tomera. 1987. "Analysis and Synthesis of Research on Responsible Environmental Behavior: A Meta-Analysis." Journal of Environmental Education 18(2): 1-8.

Hunt, Kathleen P. 2014. “It's More Than Planting Trees, It's Planting Ideas': Ecofeminist Praxis in the Green Belt Movement." Southern Communication Journal 79(3): 235-49.

Hunter, Wendy, and Natasha Borges Sugiyama. 2014. "Transforming Subjects into Citizens: Insights from Brazil's Bolsa Família." Perspectives on Politics 12(4): 829-45.

Izzi Dien, Mawil. 2000. The Environmental Dimensions of Islam. Cambridge: Lutterworth.

Javeline, Debra. 2014. "The Most Important Topic Political Scientists Are Not Studying: Adapting to Climate Change." Perspectives on Politics 12(2): 420-34.

Karp, Jeffrey A., and Susan A. Banducci. 2008. "Political Efficacy and Participation in Twenty- Seven Democracies: How Electoral Systems Shape Political Behaviour." British Journal of Political Science 38(2): 311-34.

Khadiagala, Gilbert. 2019. "Persistent Ethnic Polarization in Kenya." In Democracies Divided: The Global Challenge of Political Polarization, ed. Thomas Carothers and Andrew O'Donohue, 38-62. Washington, DC: Brookings Institution Press.

Kituyi, Mukhisa. 1985. "The State and the Pastoralists: The Marginalization of the Kenyan Maasai." Bergen: Christen Michelsens Institute Development Research and Action Programme Working Paper.

Kohut, Andrew. 2013. Climate Change and Financial Instability Seen as Top Global Threats. Washington, DC: Pew Research Center. (https://www.pewresearch.org/ global/wp-content/uploads/sites/2/2013/06/PewResearch-Center-Global-Attitudes-Project-GlobalThreats-Report-FINAL-June-24-20131.pdf).

Kresse, Kai. 2009. "Muslim Politics in Postcolonial Kenya: Negotiating Knowledge on the Doubleperiphery." Journal of the Royal Anthropological Institute 15: S76-S94.

Lam, San-Pui. 2006. "Predicting Intention to Save Water: Theory of Planned Behavior, Response Efficacy, Vulnerability, and Perceived Efficiency of Alternative Solutions." Journal of Applied Social Psychology 36(11): 2803-24.

Leinweber, Ashley E. 2012. "The Muslim Minority of the Democratic Republic of Congo: From Historic
Marginalization and Internal Division to Collective Action." Cahiers d'Études Africaines 52(206-207): 517-44.

Lerman, Amy E., and Vesla M. Weaver. 2014. Arresting Citizenship: The Democratic Consequences of American Crime Control. Chicago: University of Chicago Press.

Lewis, Gregory B., Risa Palm, and Bo Feng. 2019. "Cross-National Variation in Determinants of Climate Change Concern." Environmental Politics 28(5): 793-821.

Lubell, Mark, Sammy Zahran, and Arnold Vedlitz. 2007. "Collective Action and Citizen Responses to Global Warming." Political Behavior 29(3): 391-413.

Maathai, Wangari. 2003. The Green Belt Movement: Sharing the Approach and the Experience. Herndon: Lantern Books.

Magaloni, Beatriz, Alberto Díaz-Cayeros, and Alexander Ruiz Euler. 2019. "Public Good Provision and Traditional Governance in Indigenous Communities in Oaxaca, Mexico." Comparative Political Studies 52(12): 1841-80.

McAdam, Doug. 1999. Political Process and the Development of Black Insurgency, 1930-1970. Chicago: University of Chicago Press.

McAdam, Doug, and Hilary Boudet. 2012. Putting Social Movements in Their Place: Explaining Opposition to Energy Projects in the United States, 2000-2005. New York: Cambridge University Press.

McCauley, John. 2014. "The Political Mobilization of Ethnic and Religious Identities in Africa." American Political Science Review 108(4): 801-16.

McClendon, Gwyneth H., and Rachel Beatty Riedl. 2019. From Pews to Politics: Religious Sermons and Political Participation in Africa. Cambridge: Cambridge University Press.

McCright, Aaron M., and Riley E. Dunlap. 2011. "The Politicization of Climate Change and Polarization in the American Public's Views of Global Warming, 2001-2010." Sociological Quarterly 52(2): 155-94.

McDaniel, Eric L. 2009. Politics in the Pews: The Political Mobilization of Black Churches. Anne Arbor: University of Michigan Press.

Mettler, Suzanne, and Joe Soss. 2004. "The Consequences of Public Policy for Democratic Citizenship: Bridging Policy Studies and Mass Politics." Perspectives on Politics 2(1): 55-73.

Michaelson, Marc. 1994. "Wangari Maathai and Kenya's Green Belt Movement: Exploring the Evolution and Potentialities of Consensus Movement Mobilization." Social Problems 41(4): 540-61.

Mogire, Edward, and Kennedy Mkutu Agade. 2011. "Counter-Terrorism in Kenya." Journal of Contemporary African Studies 29(4): 473-91.

Mohai, Paul. 1985. "Public Concern and Elite Involvement in Environmental-Conservation Issues." Social Science Quarterly 66(4): 820. 
Mokken, Robert Jan. 1971. A Theory and Procedure of Scale Analysis: With Applications in Political Research. The Hague: Mouton.

Morrell, Michael E. 2003. "Survey and Experimental Evidence for a Reliable and Valid Measure of Internal Political Efficacy." Public Opinion Quarterly 67(4): 589-602.

Moser, Caroline, Andrew Norton, Alfredo Stein, and Sophia Georgieva. 2010. "Pro-Poor Adaptation to Climate Change in Urban Centers: Case Studies of Vulnerability and Resilience in Kenya and Nicaragua." World Bank Report No. 54947-GLB. Washington, DC: World Bank.

Ndiso, John. 2019. "Kenya's High Court Unanimously Upholds Ban on Gay Sex." Reuters, May 24. (https:// af.reuters.com/article/topNews/idAFKCN1SU1M7OZATP).

Ndzovu, Hassan J. 2014. Muslims in Kenyan Politics: Political Involvement, Marginalization, and Minority Status. Evanston, IL: Northwestern University Press.

Nie, Norman H., G. Bingham Powell, and Kenneth Prewitt. 1969. "Social Structure and Political Participation: Developmental Relationships, II." American Political Science Review 63(3): 808-32.

Niemi, Richard G., Stephen C. Craig, and Franco Mattei. 1991. "Measuring Internal Political Efficacy in the 1988 National Election Study." American Political Science Review 85(4): 1407-13.

Notre Dame Global Adaptation Initiative. 2019. "Country Index." (https://gain.nd.edu/our- work/ country-index/).

Oded, Arye. 2000. Islam and Politics in Kenya. Boulder, CO: Lynne Rienner Publishers.

Ongoma, Victor, Haishan Chen, and George William Omony. 2018. "Variability of Extreme Weather Events over the Equatorial East Africa: A Case Study of Rainfall in Kenya and Uganda." Theoretical and Applied Climatology 131(1-2): 295-308.

Ostrom, Elinor. 1990. Governing the Commons: The Evolution of Institutions for Collective Action. Cambridge: Cambridge University Press.

Ojwang, Lenice, Sergio Rosendo, Louis Celliers, David Obura, Anastasia Muiti, James Kamula, and Maina Mwangi. 2017. "Assessment of Coastal Governance for Climate Change Adaptation in Kenya." Earth's Future 5(11): 1119-32.

Oyugi, Walter O. 1997. "Ethnicity in the Electoral Process: The 1992 General Elections in Kenya." African Journal of Political Science/Revue Africaine de Science Politique 2(1): 41-69.

Parker, Julia Dawn, and Maureen H. McDonough. 1999. "Environmentalism of African Americans: An Analysis of the Subculture and Barriers Theories." Environment and Behavior 31(2): 155-77.
Poushter, Jacob, and Christine Huang. 2019. "Climate Change Still Seen as the Top Global Threat, But Cyberattacks a Rising Concern.” Pew Research Center, February 10. (https://www.pewresearch.org/ global/2019/02/10/climate-change-still-seen-as-thetop-global-threat-but-cyberattacks-a-rising-concern/).

Ramírez, Ricardo. 2013. Mobilizing Opportunities: The Evolving Latino Electorate and the Future of American Politics. Charlottesville: University of Virginia Press.

Riker, William H., and Peter C. Ordeshook. 1970. "A Theory of the Calculus of Voting." American Political Science Review 62(1): 25-41.

Riofrancos, Thea N. 2017. "Scaling Democracy: Participation and Resource Extraction in Latin America." Perspectives on Politics 15(3): 678-96.

Roser-Renouf, Connie, Edward W. Maibach, Anthony Leiserowitz, and Xiaoquan Zhao. 2014. "The Genesis of Climate Change Activism: From Key Beliefs to Political Action." Climatic Change 125(2): 163-78.

Ross, Marc Howard. 1975. "Political Alienation, Participation, and Ethnicity: An African Case." American Journal of Political Science 19(2): 291-311.

Sabar-Friedman, Galia. 1997. "Church and State in Kenya, 1986-1992: The Churches' Involvement in the 'Game of Change'." African Affairs 96(382): 25-52.

Saniotis, Arthur. 2012. "Muslims and Ecology: Fostering Islamic Environmental Ethics." Contemporary Islam 6 (2): 155-71.

Schlosberg, David. 2004. "Reconceiving Environmental Justice: Global Movements and Political Theories." Environmental Politics 13(3): 517-40.

Selormey, Edem, and Carolyn Logan. 2019. "African Nations Are Among Those Most Vulnerable to Climate Change. A New Survey Suggests They Are Also the Least Prepared." Monkey Cage at the Washington Post, September 23. (https://www.washingtonpost.com/ politics/2019/09/23/african-nations-are-among-thosemost-vulnerable-climate-change-new-survey-suggeststhey-are-also-least-prepared).

Shingles, Richard D. 1981. "Black Consciousness and Political Participation: The Missing Link." American Political Science Review 75(1): 76-91.

Sidanius, Jim, Sarah Cotterill, Jennifer SheehySkeffington, Nour Kteily, and Héctor Carvacho. 2016. "Social Dominance Theory: Explorations in the Psychology of Oppression." In The Cambridge Handbook of the Psychology of Prejudice, ed. Chris Sibley and Fiona Kate Barlow. Cambridge: Cambridge University Press.

Smith, Amy Erica, and Robin Globus Veldman. 2020. "Evangelical Environmentalists? Evidence from Brazil." Journal for the Scientific Study of Religion 59(2): 341-59. Soss, Joe, and Vesla Weaver. 2017. "Police Are Our Government: Politics, Political Science, and the 
Policing of Race-Class Subjugated Communities." Annual Review of Political Science 20: 565-91.

Sperber, Elizabeth, and Erin Hern. 2018. "Pentecostal Identity and Citizen Engagement in Sub-Saharan Africa: New Evidence from Zambia." Politics and Religion 11(4): 830-62.

Tabuchi, Hiroko, Michael Corkery, and Carlos Mureithi. 2020. "Big Oil Is in Trouble. Its Plan: Flood Africa with Plastic.” New York Times, August 30. (https:// www.nytimes.com/2020/08/30/climate/oil-kenyaafrica-plastics-trade.html).

Thomas, Melanee. 2012. "The Complexity Conundrum: Why Hasn't the Gender Gap in Subjective Political Competence Closed?" Canadian Journal of Political Science/Revue canadienne de science politique 45(2): 337-58.

Truth, Justice and Reconciliation Commission of Kenya. 2008. Commissions of Inquiry Report on Concerns of Muslim Community (Sharawe Report). IX. Government Documents and Regulations. 3. (https:// digitalcommons.law.seattleu.edu/tjrc-gov/3).

United States Department of State. 2018. Kenya 2018 International Religious Freedom Report. Bureau of Democracy, Human Rights, and Labor. (https:// www.justice.gov/eoir/page/file/1182256).
Veldman, Robin Globus. 2020. The Gospel of Climate Skepticism: Why Evangelical Christians Oppose Action on Climate Change. Berkeley: University of California Press. Verba, Sidney, Kay Lehman Schlozman, and Henry E. Brady. 1995. Voice and Equality: Civic Voluntarism in American Politics. Cambridge: Harvard University Press.

Vittori, Jodi, Kristin Bremer, and Pasquale Vittori. 2009. "Islam in Tanzania and Kenya: Ally or Threat in the War on Terror?" Studies in Conflict \& Terrorism 32(12): 1075-99.

Wald, Kenneth D., and Allison Calhoun-Brown. 1997. Religion and Politics in the United States. Lanham, MD: Rowman \& Littlefield.

Weaver, Vesla M., and Amy E. Lerman. 2010. "Political Consequences of the Carceral State." American Political Science Review 104(4): 817-33.

West, Emily A. 2017. "Descriptive Representation and Political Efficacy: Evidence from Obama and Clinton." Journal of Politics 79(1): 351-55.

White, Ariel. 2019. "Misdemeanor Disenfranchisement? The Demobilizing Effects of Brief Jail Spells on Potential Voters." American Political Science Review 113(2): 311-24. Zepeda-Millán, Chris. 2017. Latino Mass Mobilization: Immigration, Racialization, and Activism. Cambridge: Cambridge University Press. 